\title{
Biochemical Changes in Groundnut Genotypes against Tikka Disease of Groundnut
}

\author{
J.M. Parbat*, M.Y. Nadare and K.T. Thakare \\ Department of Plant Pathology Section, College of Agriculture, Nagpur, India \\ *Corresponding author
}

\begin{abstract}
Keywords
Total phenol, Total sugar,

Total chlorophyll, Early

leaf spot, Late leaf spot, groundnut genotypes

Article Info

Accepted:

12 August 2018

Available Online:

10 September 2018 randomized block design with three replications. Biochemical constituents of phenol, total sugar and chlorophyll at 45-50DAS (flowering stage) and 90DAS (pod development stage) were estimated from leaves of healthy and diseased samples. Forty genotypes of groundnut were screened for tikka disease under field condition. The biochemical changes (total phenol, total sugar and total chlorophyll) in tikka disease were studied in resistant and susceptible genotypes. The high total phenol content was observed in resistant genotypes than in susceptible genotypes and also total sugar content was observed maximum in resistant than susceptible genotypes. The maximum total chlorophyll content was observed in resistant genotypes compared to susceptible genotypes. The phenol and sugar contents increased with the progress of disease with the depletion of chlorophyll content. There was a significant difference in total phenol, total sugar, total chlorophyll contents between the healthy and diseased leaves of resistant and susceptible genotypes. Total phenol and total sugar are the biochemical constituents found more in resistant genotypes and considered as parameter for disease resistance.
\end{abstract}

\section{A B S T R A C T}

An experiment was conducted at College of Agriculture, Nagpur to screen forty different groundnut genotypes against tikka disease of groundnut during kharif, 2016-17 in

\section{Introduction}

Groundnut (Arachis hypogaea L.) is one of the principle oilseed crops of the world. 44-55\%. Groundnut oil is used for cooking; kernels are eaten raw, roasted and salted or swetelled.

They are rich in protein (22-32\%), carbohydrates $(20 \%)$ and contain vitamins A, $\mathrm{E}, \mathrm{K}$ and $\mathrm{B}$ groups. It is also one of the richest sources of $\mathrm{B}_{1}$. Groundnut cake, formed after the oil extraction is a highly proteinacious animal feed.
Groundnut crop often suffers from many fungal, bacterial, viral, phytoplasma, nematode diseases and pests. The major biotic factors affecting groundnut yield and quality in India are foliar fungal diseases, stem rot, collar rot, root rot, rust and seedling rots etc. Early (Cercospora arachidicola Hori.) and late leaf spots (Phaeoisariopsis personata Berk. and Curt.) are the most widely distributed and economically important foliar diseases of groundnut causing severe damage to the crop (Subrahmanyam et al., 1985). Each disease alone is capable of causing substantial 
yield loss but when they occur together losses are further increased. For instance, rust and late leaf spot together can cause up to 70 per cent yield loss also have an adverse influence on seed quality and grade characteristics, deteriorate the quality of plant biomass and thus render the fodder quality production in groundnut growing in Vidarbha region (Maharashtra). Early and late leaf spot commonly called as "Tikka disease". Loss of production from the combined effect of the both leaf spot can ranges from 10-50 per cent depending on the time of appearance and weather. These diseases damage the plant by reducing the leaf area available for photosynthesis and stimulating the leaflet abscission leading to heavy defoliation (Subrahmanyam et al., 1985). Use of disease resistant cultivators is one of the best means of reducing crop losses from leaf spot disease. Considering the importance of disease, this study was undertaken with the objectives to screen the groundnut germplasm against tikka disease and to study biochemical constituents of germplasm against tikka disease.

\section{Materials and Methods}

\section{Laboratory experiment}

Laboratory, experiment was conducted to estimate the phenol, total sugar and chlorophyll at 45-50 DAS (flowering stage) and 90 DAS (pod development stage). The above biochemical constituents were estimated from leaves of healthy and diseased sample of categorised germplasm of groundnut which were collected from experimental field of Plant Pathology, College of Agriculture, Nagpur. Total phenols were estimated using method described by Malik and Singh (1980). Estimation of sugar content both reducing and non-reducing sugar from healthy and diseased leaves was estimated by titrimetric method using Benedict's quantitative reagent (Benedict, 1907).
Estimation of chlorophyll was extracted in 80 per cent acetone and absorbance at $663 \mathrm{~nm}$ and $645 \mathrm{~nm}$ are read in a spectrophotometer (Gupta et al., 1987).

\section{Results and Discussion}

\section{Symptoms of tikka disease of groundnut}

The symptoms produced by two pathogens viz., Cercospora arachidicola and Phaeoisariopsis personata were different in size, shape and colour of lesions. Phaeoisariopsis personata spots at maturity were black on both the surface of leaf with lower surface attaining different shades. The size of spots varied from 1.5 to $3.5 \mathrm{~mm}$. Halos around mature spots attain a golden yellow. Cercospora arachidicola were dark brown on leaf surface.

The spot varied in size from 3 to $5 \mathrm{~mm}$ from round to irregular in size, when they turned yellow to golden and generally lighter than Phaeoisariopsis personata. Similar to this observations Ramakrishna and Appa Rao (1968) reported that apart from the time of appearance, the symptoms produced by two pathogens viz. Cercospora arachidicola and Cercospora personata different in size, shape and colour of lesions. The symptoms of Phaeoisariopsis personata which appeared on the upper surface of older leaves were dark brown to black spots measuring 1 to $6 \mathrm{~mm}$ in diameter almost circular in out and with distinct pale yellow margin. Cercospora arachidicola produced reddish brown more or less circular to irregular lesions measuring about 1 to $10 \mathrm{~mm}$ in diameter and surrounded by a narrow bright yellow halo.

These observations correlated with findings of Mayee and Datar (1988), who reported that the symptoms of Cercospora personata which appeared on the upper surface of older leaves were dark brown to black spots. 


\section{Biochemical analysis}

At the same time screening of groundnut genotypes in natural field condition was also done. The healthy and infected sample of leaves at flowering and pod development stages were collected for detection of biochemical analysis as described in material and methods.

\section{Phenol estimation}

It is apparent from the table 1 that there was a significant difference in total phenol contents between the healthy and diseased leaves of resistant and susceptible genotypes. The highly resistant genotype ACGGV-3 had higher total phenol content 0.83 and $1.69 \mathrm{mg}$ $\mathrm{g}^{-1}$ dry wt. in healthy and diseased leaves. Resistant genotype Kopergaon-3 had 0.76 and $1.43 \mathrm{mg} \mathrm{g}^{-1}$ dry wt.; moderately resistant genotype ACNGV-2 had 0.71 and $1.38 \mathrm{mg} \mathrm{g}^{-1}$ dry wt.; susceptible genotype ACNGV-4 had 0.67 and $1.27 \mathrm{mg} \mathrm{g}^{-1}$ dry wt.; highly susceptible genotype TAG-24 had 0.61 and $1.23 \mathrm{mg} \mathrm{g}^{-1}$ dry wt. in healthy and diseased leaf samples respectively at flowering stage
(ELS). It is evident from data presented in the table 2 that there was a significant difference in total phenol contents between the healthy and diseased leaves of resistant and susceptible genotypes. Resistant genotype Kopergaon-3 had 1.02 and $2.13 \mathrm{mg} \mathrm{g}^{-1}$ dry wt.; moderately resistant genotype ACGGV30 had 0.96 and $1.89 \mathrm{mg} \mathrm{g}^{-1}$ dry wt.; susceptible genotype TAG-24 had 0.87 and $1.72 \mathrm{mg} \mathrm{g}^{-1}$ dry wt.; highly susceptible genotype ACNGV-16 had 0.71 and $1.59 \mathrm{mg}$ $\mathrm{g}^{-1}$ dry wt. in healthy and diseased leaves samples respectively at pod development stage (LLS). In accordance to this result Bhaskar and Parakhia (2010) studied the biochemical changes in tikka disease caused by pathogens Cercospora arachidicola (Hori.) and Phaeoisariopsis personata (Berk. and Curt.) for two susceptible cultivars (GG-2 and GG-7) and two resistant cultivars (ICGV-86590 and ICGV-86564) of groundnut at 35 and 90 days after sowing and reported higher total phenol content in resistance varieties than susceptible ones. The total phenol content at different stages of infection showed that it increased with the progress of infection in resistant and susceptible varieties also.

\section{Table.1 Effect of early leaf spot on total phenol content of groundnut Genotypes at flowering stage}

\begin{tabular}{|l|c|c|c|}
\hline \multicolumn{1}{|c|}{ Genotypes } & Reaction & \multicolumn{2}{|c|}{ Total phenol $\left(\mathbf{m g ~ g}^{-\mathbf{1}}\right.$ dry wt.) } \\
\cline { 2 - 4 } & & Healthy & Diseased \\
\hline ACGGV-30 & HR & 0.83 & 1.69 \\
\hline Kopergaon-3 & R & 0.76 & 1.43 \\
\hline ACNGV-2 & MR & 0.71 & 1.38 \\
\hline ACNGV-4 & S & 0.67 & 1.27 \\
\hline TAG-24 & HS & 0.61 & 1.23 \\
\hline SEm \pm & & $\mathbf{0 . 0 2 6 3}$ & $\mathbf{0 . 0 2 2 2}$ \\
\hline CD $(\mathbf{P = 0 . 0 5 )}$ & & $\mathbf{0 . 0 7 9 9}$ & $\mathbf{0 . 0 6 7 4}$ \\
\hline
\end{tabular}


Table.2 Effect of late leaf spot on total phenol content of groundnut genotypes at pod development stage

\begin{tabular}{|l|c|c|c|}
\hline \multirow{2}{*}{ Genotypes } & \multirow{2}{*}{ Reaction } & \multicolumn{2}{c|}{ Total phenol $\left(\mathbf{m g ~ g}^{-\mathbf{1}} \mathbf{d r y} \mathbf{w t}\right.$ ) } \\
\cline { 2 - 4 } & & Healthy & Diseased \\
\hline Kopergaon-3 & $\mathrm{R}$ & 1.02 & 2.13 \\
\hline ACGGV-30 & MR & 0.96 & 1.89 \\
\hline TAG-24 & $\mathrm{S}$ & 0.87 & 1.72 \\
\hline ACNGV-16 & HS & 0.71 & 1.59 \\
\hline SEm \pm & & $\mathbf{0 . 0 2 1 3}$ & $\mathbf{0 . 0 1 1 0}$ \\
\hline CD $(\mathbf{P = 0 . 0 5 )}$ & & $\mathbf{0 . 0 6 9 6}$ & $\mathbf{0 . 0 3 2 6}$ \\
\hline
\end{tabular}

Table.3 Effect of early leaf spot on total sugar $\left(\mathrm{mg} \mathrm{g}^{-1}\right.$ dry wt.) content of groundnut genotypes at flowering stage

\begin{tabular}{|l|c|c|c|c|c|c|c|}
\hline \multirow{2}{*}{ Genotypes } & Reaction & \multicolumn{2}{|c|}{ Reducing sugar } & \multicolumn{2}{|c|}{ Non- Reducing sugar } & \multicolumn{2}{c|}{ Total sugar } \\
\cline { 2 - 8 } & & Healthy & Diseased & Healthy & Diseased & Healthy & Diseased \\
\hline ACGGV-30 & HR & 10.12 & 12.34 & 1.89 & 1.98 & 12.01 & 14.32 \\
\hline Kopergaon-3 & R & 10.09 & 12.29 & 1.79 & 1.98 & 11.88 & 14.27 \\
\hline ACNGV-2 & MR & 9.85 & 11.56 & 1.58 & 1.72 & 11.43 & 13.28 \\
\hline ACNGV-4 & S & 9.21 & 11.09 & 1.18 & 1.42 & 10.39 & 12.51 \\
\hline TAG-24 & HS & 8.91 & 10.07 & 1.01 & 1.11 & 9.92 & 11.18 \\
\hline SEm \pm & & $\mathbf{0 . 0 1 4}$ & $\mathbf{0 . 0 3 2}$ & $\mathbf{0 . 0 3 1}$ & $\mathbf{0 . 0 2 3}$ & $\mathbf{0 . 0 3 1}$ & $\mathbf{0 . 0 3 3}$ \\
\hline CD $(\mathbf{P = 0 . 0 5 )}$ & & $\mathbf{0 . 0 4 3}$ & $\mathbf{0 . 0 9 8}$ & $\mathbf{0 . 0 9 4}$ & $\mathbf{0 . 0 7}$ & $\mathbf{0 . 0 9 6}$ & $\mathbf{0 . 1}$ \\
\hline
\end{tabular}

Table.4 Effect of late leaf spot on total sugar ( $\mathrm{mg} \mathrm{g}^{-1}$ dry wt.) content of groundnut genotypes at pod development stage

\begin{tabular}{|l|c|c|c|c|c|c|c|}
\hline \multirow{2}{*}{ Genotypes } & Reaction & \multicolumn{2}{|c|}{ Reducing sugar } & \multicolumn{2}{c|}{ Non- Reducing sugar } & \multicolumn{2}{c|}{ Total sugar } \\
\cline { 2 - 8 } & & Healthy & Diseased & Healthy & Diseased & Healthy & Diseased \\
\hline Kopergaon-3 & R & 14.68 & 15.21 & 1.2 & 1.28 & 15.88 & 16.49 \\
\hline ACGGV-30 & MR & 13.65 & 15.14 & 1.14 & 1.21 & 14.67 & 16.35 \\
\hline TAG-24 & S & 13.35 & 15.02 & 1.09 & 1.17 & 14.44 & 16.19 \\
\hline ACNGV-16 & HS & 13.11 & 14.79 & 1.02 & 1.12 & 14.13 & 15.91 \\
\hline SEm \pm & & $\mathbf{0 . 0 1 6 3}$ & $\mathbf{0 . 0 1 5 6}$ & $\mathbf{0 . 0 1 3 7}$ & $\mathbf{0 . 0 1 9 7}$ & $\mathbf{0 . 0 1 7}$ & $\mathbf{0 . 0 1 0 0}$ \\
\hline CD $(\mathbf{P = 0 . 0 5})$ & & $\mathbf{0 . 0 5 3 3}$ & $\mathbf{0 . 0 5 1}$ & $\mathbf{0 . 0 4 4 8}$ & $\mathbf{0 . 0 6 4 3}$ & $\mathbf{0 . 0 5 5}$ & $\mathbf{0 . 0 3 2 6}$ \\
\hline
\end{tabular}


Table.5 Effect of early leaf spot on total chlorophyll ( $\mathrm{mg} \mathrm{g}^{-1}$ dry wt.) content of groundnut genotypes at flowering stage

\begin{tabular}{|l|c|c|c|c|c|c|c|}
\hline Genotypes & Reaction & $\begin{array}{c}\text { Chlorophyll } \\
\mathbf{a}\end{array}$ & $\begin{array}{c}\text { Chlorophyll } \\
\text { b }\end{array}$ & $\begin{array}{c}\text { Total } \\
\text { chlorophyll } \\
\text { Healthy }\end{array}$ & $\begin{array}{c}\text { Chlorophyll } \\
\mathbf{a}\end{array}$ & $\begin{array}{c}\text { Chlorophyll } \\
\text { b }\end{array}$ & $\begin{array}{c}\text { Total } \\
\text { chlorophyll } \\
\text { Diseased }\end{array}$ \\
\hline ACGGV-30 & HR & 1.09 & 0.52 & 1.61 & 0.76 & 0.47 & 1.23 \\
\hline Kopergaon-3 & R & 1.07 & 0.5 & 1.57 & 0.68 & 0.42 & 1.10 \\
\hline ACNGV-2 & MR & 0.98 & 0.54 & 1.52 & 0.61 & 0.41 & 1.02 \\
\hline ACNGV-4 & S & 0.93 & 0.48 & 1.41 & 0.56 & 0.43 & 0.99 \\
\hline TAG-24 & HS & 0.9 & 0.48 & 1.38 & 0.49 & 0.41 & 0.90 \\
\hline S.E. (m) \pm & & $\mathbf{0 . 0 2 8}$ & $\mathbf{0 . 0 3 1}$ & $\mathbf{0 . 0 5 3}$ & $\mathbf{0 . 0 1 9}$ & $\mathbf{0 . 0 1 2}$ & $\mathbf{0 . 0 1 6}$ \\
\hline C.D (P=0.05) & & $\mathbf{0 . 0 8 6}$ & $\mathbf{0 . 0 9 0}$ & $\mathbf{0 . 1 6 1}$ & $\mathbf{0 . 0 5 7}$ & $\mathbf{0 . 0 3 7}$ & $\mathbf{0 . 0 4 8}$ \\
\hline
\end{tabular}

Table.6 Effect of late leaf spot on total chlorophyll ( $\mathrm{mg} \mathrm{g}^{-1}$ dry wt.) content of groundnut genotypes at pod development stage

\begin{tabular}{|l|c|c|c|c|c|c|c|}
\hline Genotypes & Reaction & $\begin{array}{c}\text { chlorophyll } \\
\mathbf{a}\end{array}$ & $\begin{array}{c}\text { chlorophyll } \\
\text { b }\end{array}$ & $\begin{array}{c}\text { Total } \\
\text { chlorophyll } \\
\text { Healthy }\end{array}$ & $\begin{array}{c}\text { Chlorophyll } \\
\mathbf{a}\end{array}$ & $\begin{array}{c}\text { chlorophyll } \\
\text { b }\end{array}$ & $\begin{array}{c}\text { Total } \\
\text { chlorophyll } \\
\text { Diseased }\end{array}$ \\
\hline Kopergaon-3 & $\mathrm{R}$ & 0.98 & 0.38 & 1.36 & 0.61 & 0.28 & 0.89 \\
\hline ACGGV-30 & MR & 0.86 & 0.4 & 1.26 & 0.52 & 0.24 & 0.76 \\
\hline TAG-24 & S & 0.72 & 0.46 & 1.18 & 0.48 & 0.21 & 0.69 \\
\hline ACNGV-16 & HS & 0.69 & 0.41 & 1.10 & 0.42 & 0.19 & 0.61 \\
\hline SEm \pm & & $\mathbf{0 . 0 3 4 2}$ & $\mathbf{0 . 0 1 2 5}$ & $\mathbf{0 . 0 3 3 7}$ & $\mathbf{0 . 0 1 8}$ & $\mathbf{0 . 0 1 0 0}$ & $\mathbf{0 . 0 3 0 9}$ \\
\hline CD $(\mathbf{P}=\mathbf{0 . 0 5})$ & & $\mathbf{0 . 1 1 1 4}$ & $\mathbf{0 . 0 4 0 7}$ & $\mathbf{0 . 1 0 9 8}$ & $\mathbf{0 . 0 5 8 5}$ & $\mathbf{0 . 0 3 2 6}$ & $\mathbf{0 . 1 0 0 8}$ \\
\hline
\end{tabular}

\section{Total sugar estimation}

The data presented in the table 3 revealed that there was a significant difference in total sugar contents between the healthy and diseased leaves of resistant and susceptible genotypes. The highly resistant genotype ACGGV-30 had higher total sugar of 12.01 and $14.32 \mathrm{mg} \mathrm{g}^{-1}$ dry wt. in healthy and diseased leaves. Resistant genotype Kopergaon-3 had 11.88 and $14.27 \mathrm{mg} \mathrm{g}^{-1}$ dry wt.; moderately resistant genotype ACNGV-2 had 11.43 and $13.28 \mathrm{mg} \mathrm{g}^{-1}$ dry wt.; susceptible genotype ACNGV-4 had 10.39 and 12.51 ( $\mathrm{mg} \mathrm{g}^{-1}$ dry wt.); highly susceptible genotype TAG-24 contains 9.92 and 11.18 $\mathrm{mg} \mathrm{g}^{-1}$ dry wt. in healthy and diseased leaves samples respectively at flowering stage
(ELS). The data presented in the table 4 showed that there was a significant difference in total sugar contents between the healthy and diseased leaves of resistant and susceptible genotypes. Resistant genotype Kopergaon-3 had 15.88 and $16.49 \mathrm{mg} \mathrm{g}^{-1}$ dry wt.; moderately resistant genotype ACGGV30 had 14.67 and $16.35 \mathrm{mg} \mathrm{g}^{-1}$ dry wt.; susceptible genotype TAG-24 had 14.44 and $16.19 \mathrm{mg} \mathrm{g}^{-1}$ dry wt.; highly susceptible genotype ACNGV-16 had 14.13 and 15.91 $\mathrm{mg} \mathrm{g}^{-1}$ dry wt. in healthy and diseased leaves samples respectively at pod development stage (LLS). In accordance to this result Bhaskar and Parakhia (2010) studied the biochemical changes in tikka disease caused by pathogens Cercospora arachidicola (Hori.) and Phaeoisariopsis personata (Berk. 
and Curt.) for two susceptible cultivars (GG-2 and GG-7) and two resistant cultivars (ICGV86590 and ICGV-86564) of groundnut at 35 and 90 days after sowing and reported the maximum soluble sugar in resistance varieties than susceptible ones. The soluble sugar contents at different stages of infection showed that soluble sugar increased with the progress of infection in resistant and susceptible varieties also.

\section{Total chlorophyll estimation}

There was a significant difference in total chlorophyll between the healthy and diseased leaves of resistant and susceptible genotypes. Data showed in table 5 revealed that highly resistant genotype ACGGV-30 had higher total chlorophyll of 1.61 and $1.23 \mathrm{mg} \mathrm{g}^{-1}$ dry wt. in healthy and diseased leaves. Resistant genotype Kopergaon-3 had 1.57 and $1.10 \mathrm{mg}$ $\mathrm{g}^{-1}$ dry wt.; moderately resistant genotype ACNGV-2 had 1.52 and $1.02 \mathrm{mg} \mathrm{g}^{-1}$ dry wt.; susceptible genotype ACNGV-4 had 1.41 and $0.99 \mathrm{mg} \mathrm{g}^{-1}$ dry wt.; highly susceptible genotype TAG-24 had 1.38 and $0.90 \mathrm{mg} \mathrm{g}^{-1}$ dry wt. in healthy and diseased leaves samples respectively at flowering stage (ELS). The data presented in the table 6 revealed that there was a significant difference in total chlorophyll between the healthy and diseased leaves of resistant and susceptible genotypes. Resistant genotype Kopergaon-3 had 1.36 and $0.89 \mathrm{mg} \mathrm{g}^{-1}$ dry wt.; moderately resistant genotype ACGGV30 had 1.26 and $0.76 \mathrm{mg} \mathrm{g}^{-1}$ dry wt.; susceptible genotype TAG-24 had 1.18 and $0.69 \mathrm{mg} \mathrm{\textrm {g } ^ { - 1 }}$ dry wt.; highly susceptible genotype ACNGV-16 had 1.10 and $0.61 \mathrm{mg}$ $\mathrm{g}^{-1}$ dry wt. in healthy and diseased leaves samples respectively at pod development stage (LLS). In accordance to this result Bhaskar and Parakhia (2010) studied the biochemical changes in tikka disease caused by pathogens Cercospora arachidicola (Hori.) and Phaeoisariopsis personata (Berk. and Curt.) for two susceptible cultivars (GG-2 and GG-7) and two resistant cultivars (ICGV86590 and ICGV-86564) of groundnut at 35 and 90 days after sowing and reported that chlorophyll contents at different stages of infection showed that the chlorophyll contents decreased with the progress of infection in resistant and susceptible varieties also. The higher amount of total chlorophyll observed in resistant varieties as compared to susceptible ones.

Total phenol and total sugar were the biochemical constituents found more in resistant genotypes and considered as parameter for disease resistance. Resistance supported good growth of plant which ultimately reflects in contributing yields. Introduction of resistance in the genotypes through breeding programme can be a tool for management of the disease.

\section{References}

Benedict, S.R. 1907. The detection and estimation of reducing sugars. J. Biol. Chem. 3:101-117.

Bhaskar, A. V. and A. M. Parakhia, 2010. Biochemical changes in resistant and susceptible varieties of peanut (Arachis hypogaea) in relation to early and late leaf spot disease. Indian J. Oilseeds Res. 27 (2): 195-196.

Gupta, S. K., P. P. Gupta, C. D. Kaushik and G. S. Saharan, 1987. Biochemical changes in leaf surface extract and total chlorophyll content of sesame in relation to Alternaria leaf spot disease (Alternaria sesami). Indian J. Mycol. Plant. Path. 17 (2): 165-168.

Mayee, C. D., and V. V Datar, 1988. Phytopathometry technical bulletin-1, published by Marathawada Agriculture University, Parbhani pp.90. 
Ramakrishna, T.S. and A. Appa Rao, 1968. Studies on the tikka disease of groundnut. Indian Phytopath. 21: 31-36.

Subrahmanyam, P., V. K. Mehan, D. J. Nevill, and D. McDonald, 1980.
Research on fungal diseases of groundnut at ICRISAT pp. 193-198. Wheeler, B.E.J, 1969. An introduction to plant diseases. John Wiley and Sons Ltd., London.

\section{How to cite this article:}

Parbat, J.M., M.Y. Nadare and Thakare, K.T. 2018. Biochemical Changes in Groundnut Genotypes against Tikka Disease of Groundnut. Int.J.Curr.Microbiol.App.Sci. 7(09): 20412047. doi: https://doi.org/10.20546/ijcmas.2018.709.248 